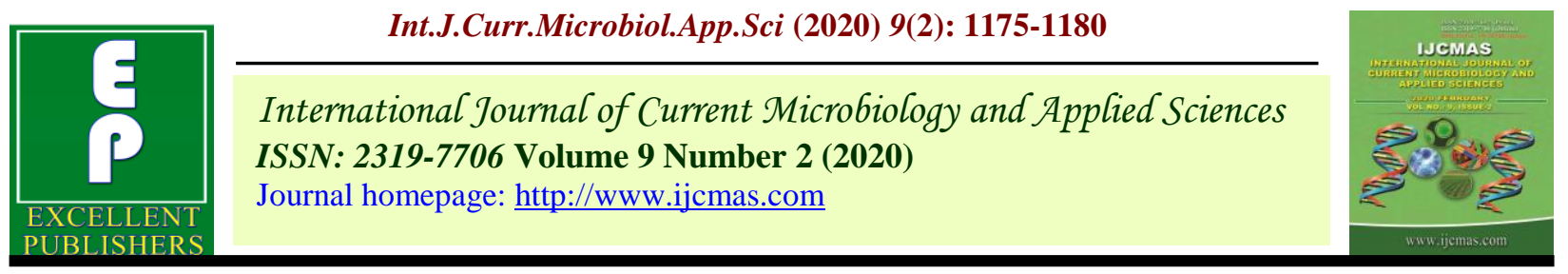

\title{
Impact of Different Organic Source of Manures, Bio-fertilizers, Rock phosphate, Green Manuring and Recycling of Organic Residue on Vegetative and Yield Traits Performance of Cashew Var. Ullal-1 under Plain Region of Karnataka, India
}

\author{
B. N. Rajendra*, M. Ramesh and B. Subramanyam \\ AICRP on Cashew, HREC, Hogalagere, Kolar, Karnataka, India \\ *Corresponding author
}

\begin{abstract}
A B S T R A C T
\end{abstract}

\begin{tabular}{|l|}
\hline Ke y w o r d s \\
Cashew, Organic \\
manures, Bio- \\
fertilizer, Rock \\
phosphate, Green \\
manuring
\end{tabular}

\begin{abstract}
The organic management of cashew research experiment was conducted during the year 2018-19 at Hogalagere, AICRP Cashew centre. The combination of treatments includes organic manures, bio-fertilizers, naturally available rock phosphate, in-situ green manuring, recommended dose of fertilizers and FYM. In this research experiment eight treatments were imposed, but plants were fed with $25 \% \mathrm{~N}$ as FYM+ Recycling of organic residue + In-situ green manuring/green leaf manuring + BFC @ 200 g /tree/year i.e., T7 was significantly elevated higher values in parameters like plant height(308 m), except T8 $(3.02 \mathrm{~m})$, stem girth $(16.25 \mathrm{~cm})$ exclude T8 $(16.02 \mathrm{~cm})$, mean nut weight $(7.05 \mathrm{~g})$ except T8 (6.93 g), nut yield (4.18 kg/plant ) except T8 $(4.05 \mathrm{~kg} / \mathrm{plant})$ and same in the case of cumulative nut yield. However among the different combination of treatments $\mathrm{T} 7$ performed as the best treatment which was followed by T8 i.e., recommended dose of fertilizers and FYM. The tea mosquito bug infestation has low impact in all the eight treatments of experiment.
\end{abstract}

\section{Introduction}

Cashew (Anacardium occidentale) is one of the most palatable dry fruit accepted in different regions of the world. It is a fast growing, hardy and drought resistant multipurpose (all parts of the tree are useful) tree species cultivated in many tropical countries. The tree can grow as high as $14 \mathrm{~m}$ ( $46 \mathrm{ft}$ ), but the dwarf cashew, growing up to $6 \mathrm{~m}$ (20 ft), has proved more profitable, with earlier maturity and higher yields. Cashew apples and cashew nuts are excellent sources of nutrition.
Cashew trees are genuinely tropical and very frost sensitive. The trees grow in a wide spectrum of climatic regions between (the 25 ${ }^{\circ} \mathrm{N}$ and $\mathrm{S}$ latitudes). Although the cashew can withstand high temperatures, a monthly mean of $25{ }^{\circ} \mathrm{C}$ is regarded as optimal. For the best production deep, well-drained sandy or sandy-loam soil is recommended. Cashew trees will not grow in poorly-drained soils. Total fat was the major component accounting for $48.3 \%$ of the total weight, of which $79.7 \%$ were unsaturated FA (fatty acids), $20.1 \%$ saturated FA, and $0.2 \%$ trans 
FA. Proteins, with $21.3 \mathrm{~g} / 100 \mathrm{~g}$, were ranked second followed by carbohydrates (20.5 g/100 g) (Ricard Rico et al., 2016)

Organic materials (both organic manures as well as wastes) for improving the physical properties of soil that allows profitable crop production (Somani and Totawat, 1996). Improvement of environmental conditions and public health are important reasons for advocating increase in use of organic materials (Seifritz, 1992 and, Maritus and Vlelc, 2001). The growing of crops by organic practices in conformity with certain standards is a process beginning from land preparation to finally reaching the produce in the hands of consumers. In fact, organic and bio-dynamic farming signify the production of a kind of chemical residue-free organic labelled products to sensitive consumers. In other words, organic is a 'process claim' rather than a 'product claim'. The utilization of chemical fertilizers is the easiest way of increasing crop yield. However, the increasing cost of fertilizers, removal of subsidies and environmental problems; the farmers are inclined to prefer organic manures over inorganic manures (Kalaivanan and Rupa, 2017). Though agricultural production has continued to increase, but productivity has started to decline. Modern chemical based agriculture practices have led to several new challenges, viz. decline in productivity, degradation of soil and water resources, diminishing biodiversity and increase in environmental pollution. The increasing awareness of adverse effect of excess use of fertilizers and pesticides in modern system of agriculture has led to the considerable interest in the use of organics and microbes as source of plant nutrients and also botanicals or bio control agents for the management of pests and diseases. Therefore, In current days the organically produced crops have been getting more emphasis in majority of the world especially in developing and developed countries and the production of organic cashew also been getting more importance in cashew growing areas.

Thus, the intension of the experiment was to study the influence of combination of different organic manure source of nutrients, bio fertilizers and naturally available materials on growth proliferation and yield augmentation of cashew in non coastal regions of Karnataka and other regions of India.

\section{Materials and Methods}

An experimental investigation was conducted during the year of 2018-19 at All India Coordinated Research Project on Cashew (AICRP on Cashew), Horticultural Research and Extension Centre, Hogalagere, Srinivasapura taluk, Kolar district, Karnataka state. The soil type of the experimental field was red loamy in texture. The experiment was laid out by RCBD design with eight treatment combinations, three replication and planted Ullal-1 variety (5 year old) with the spacing of $7 \times 7 \mathrm{~m}$. The treatment combinations are presented in the table 1 .

The irrigation was supplemented through lateral lines of $16 \mathrm{~mm}$ diameter LDPE pipes were laid along the crop rows and drip emitter served to each tree.

The vegetative and yield attributing parameters like plant height, canopy height, canopy diameter, stem girth, mean canopy surface area, ground area covered by plant canopy, flowering duration, mean apple weight, mean nut weight, nut yield and shelling percentage were recorded in different phases of growth and yield of particular season of the year. Especially stem girth was measured by vernier calliper, mean canopy diameter was calculated by taking the average canopy spread of both East-West and North- 
South directions, mean canopy surface area and ground area covered by plant canopy were calculated by following formula:

\section{Canopy surface area}

Canopy surface area $=\pi \mathrm{rl}$

Where $\mathrm{r}=$ radius of the canopy $(\mathrm{m})$

$\mathrm{r}=$ canopy diameter/2

$\mathrm{l}=\sqrt{ }$ [canopy height $(\mathrm{ch})]^{2}+\mathrm{r}^{2}$ (square root of $\left.\mathrm{ch}^{2}+\mathrm{r}^{2}\right)$

\section{Ground area covered by plant canopy}

Ground area covered by the plant canopy $=\pi$ $\mathrm{r}^{2}$

Where $r=$ radius of the canopy $(\mathrm{m})$

$\mathrm{r}=$ canopy diameter $/ 2$

Canopy diameter $=($ Length of canopy EW + length of canopy NS)/2

Flowering duration was computed by taking the difference of the date of first flowering (when the tree attained 50\% of the flowering) and date of last flowering (when only 50\% of flowers retained in the plant canopy) and the shelling percentage was determined by dividing the weight of kernel with testa by the weight of nut (weight of kernel with testa + weight of shell) and expressed as percentage. The data's were analyzed statistically by suitable the procedure (Panse and Sukhatme, 1995).

\section{Results and Discussion}

Influence of the combination of treatments includes organic manures, bio-fertilizers, naturally available rock phosphate, in-situ green manuring, recommended dose of fertilizers and FYM. In this research experiment eight treatments were imposed with control check (Recommended dose of fertilizer $+10 \mathrm{Kg}$ FYM $-\mathrm{T}_{8}$ ) as given in the table 1 . The results of the growth and yield attributes of experiment were recorded in different phases of the crop growth period and mean average values were analyzed statistically by suitable the procedure (Panse and Sukhatme, 1995).

Among the treatment combination $\mathrm{T}_{7}$ was significantly elevated higher values with respect to plant height which was 3.08 meter and $\mathrm{T}_{7}$ was on par with $\mathrm{T}_{8}(3.02 \mathrm{~m}), \mathrm{T}_{6}(2.93$ $\mathrm{m})$, followed by $\mathrm{T}_{3}(2.92 \mathrm{~m})$ and minimum plant height was noticed in $T_{5}(2.55 \mathrm{~m})$; regarding stem girth $\mathrm{T}_{7}$ was recorded significantly higher values i.e., $16.25 \mathrm{~cm}$ excluded $\mathrm{T}_{8}(16.02 \mathrm{~cm})$ and $\mathrm{T}_{4}(15.32 \mathrm{~cm})$ meanwhile $\mathrm{T}_{6}$ was recorded least stem girth; With respect to canopy height $\mathrm{T}_{7}$ was recorded significantly higher number but it was on par with $\mathrm{T}_{8}(1.58 \mathrm{~m}), \mathrm{T}_{3}(1.50 \mathrm{~m}), \mathrm{T}_{2}$ $(1.47 \mathrm{~m})$ and $\mathrm{T}_{1}(1.44 \mathrm{~m})$ at the same time $\mathrm{T}_{5}$ was documented minimum canopy values i.e., 1.35 meters; with reference to canopy spread, mean canopy diameter, mean canopy surface area and ground area covered by plant canopy, among treatment combination there was no significant variation. However, $\mathrm{T}_{7}$ was reported higher numerical figures and adverting to above parameters $\mathrm{T}_{6}$ was registered least values (Table-2).

With regard to flowering duration and apple weight $\mathrm{T}_{8}$ was documented significantly higher figures 124 days and 36.42 grams respectively, but above figures were on par with $\mathrm{T}_{7}$ treatment figures i.e., 121 days and 35.82 grams respectively. Among the eight different treatments the shelling per cent were non significant except few treatments; with respect to mean nut weight $T_{7}$ was elevated significantly higher values(7.05grams) among the treatments exclude $\mathrm{T}_{8}(6.93$ grams $)$ and minimum value was in $\mathrm{T}_{6}$ (6.57grams); where as in case of nut yield per plant and cumulative yield( $3^{\text {rd }}$ harvest) $\mathrm{T}_{7}$ was registered significantly greater values $4.18 \mathrm{~kg}$ 
per plant and $8.65 \mathrm{~kg}$ per plant respectively and these values on par with $\mathrm{T}_{8}$ values and both parameters minimum values documented in $\mathrm{T}_{6}$ i.e., nut yield $3.02 \mathrm{~kg}$ per plant; meanwhile the Tea Mosquito Bug (TMB) infestation was recorded low irrespective of treatments (Table 3).

Table.1 Treatment details of organic management in cashew

\begin{tabular}{|c|l|}
\hline Treatment & Treatment explanation \\
\hline $\mathbf{T}_{\mathbf{1}}$ & $100 \% \mathrm{~N}$ from locally available source (sheep manure) \\
\hline $\mathbf{T}_{\mathbf{2}}$ & $100 \% \mathrm{~N}$ as sheep manure + Bio fertilizer consortium (BFC) @ 200 g/tree/year \\
\hline $\mathbf{T}_{\mathbf{3}}$ & $50 \% \mathrm{~N}$ as sheep manure + BFC @ 200g/tree/year + Rock phospate \\
\hline $\mathbf{T}_{\mathbf{4}}$ & $100 \% \mathrm{~N}$ as vermicompost +BFC @ 200g/tree/year \\
\hline $\mathbf{T}_{\mathbf{5}}$ & $\begin{array}{l}\text { Recycling of organic residue with the addition of } 20 \% \text { cowdung slurry } \\
\text { (wt.basis-20\% weight of organic residue as cow dung slurry) }\end{array}$ \\
\hline $\mathbf{T}_{\mathbf{6}}$ & In-situ green manuring ( retain litter + planting of cowpea) \\
\hline $\mathbf{T}_{\mathbf{7}}$ & $\begin{array}{l}\text { 25\% as FYM+ Recycling of organic residue +in-situ green manuring/green } \\
\text { leaf manuring +BFC @200g/tree/year }\end{array}$ \\
\hline $\mathbf{T}_{\mathbf{8}}$ & Recomended dose of fertilzer +10 Kg FYM \\
\hline
\end{tabular}

Table.2 The influence of organic manures, bio-fertilizers and other organic sources on vegetative parameters of cashew at HREC, Hogalagere during 2018-19

\begin{tabular}{|c|c|c|c|c|c|c|c|c|}
\hline \multirow[t]{2}{*}{$\begin{array}{l}\text { Treatment } \\
\text { s }\end{array}$} & \multirow[t]{2}{*}{$\begin{array}{c}\text { Plant } \\
\text { height(m) }\end{array}$} & \multirow{2}{*}{$\begin{array}{l}\text { Stem } \\
\text { girth } \\
\text { (cm) }\end{array}$} & \multirow[t]{2}{*}{$\begin{array}{c}\text { Canopy } \\
\text { height }(m)\end{array}$} & \multicolumn{2}{|c|}{$\begin{array}{c}\text { Canopy } \\
\operatorname{spread(m)}\end{array}$} & \multirow{2}{*}{$\begin{array}{c}\text { Mean } \\
\text { Canopy } \\
\text { diameter } \\
(\mathbf{m})\end{array}$} & \multirow{2}{*}{$\begin{array}{c}\text { Mean } \\
\text { canopy } \\
\text { surface } \\
\operatorname{area}\left(\mathbf{m}^{2}\right)\end{array}$} & \multirow{2}{*}{$\begin{array}{c}\text { Ground area } \\
\text { covered by } \\
\text { plant canopy } \\
(\%)\end{array}$} \\
\hline & & & & E-W & N-S & & & \\
\hline T1 & 2.76 & 14.62 & 1.44 & 2.74 & 2.71 & 2.73 & 12.38 & 11.97 \\
\hline T2 & 2.84 & 14.85 & 1.47 & 2.78 & 2.75 & 2.76 & 12.85 & 12.29 \\
\hline T3 & 2.92 & 15.04 & 1.50 & 2.81 & 2.84 & 2.83 & 13.77 & 12.92 \\
\hline T4 & 2.68 & 15.32 & 1.39 & 2.75 & 2.71 & 2.73 & 12.30 & 12.04 \\
\hline T5 & 2.55 & 14.45 & 1.35 & 2.71 & 2.76 & 2.73 & 12.05 & 11.99 \\
\hline T6 & 2.93 & 14.28 & 1.41 & 2.67 & 2.70 & 2.68 & 11.86 & 11.60 \\
\hline T7 & 3.08 & 16.25 & 1.63 & 2.92 & 2.95 & 2.94 & 15.26 & 13.85 \\
\hline T8 & 3.02 & 16.02 & 1.58 & 2.84 & 2.87 & 2.86 & 14.47 & 13.26 \\
\hline S.Em \pm & 0.07 & 0.32 & 0.06 & 0.15 & 0.15 & 0.15 & 1.54 & 1.28 \\
\hline CD at $5 \%$ & 0.22 & 0.97 & 0.19 & 0.46 & 0.45 & 0.44 & 4.66 & 3.87 \\
\hline CV & 4.45 & 3.67 & 7.44 & 9.51 & 9.14 & 9.03 & 20.27 & 17.71 \\
\hline
\end{tabular}


Table.3 The influence of organic manures, bio-fertilizers and other organic sources on yield parameters of cashew at HREC, Hogalagere during 2018-19

\begin{tabular}{|c|c|c|c|c|c|c|c|}
\hline Treatments & $\begin{array}{c}\text { Flowering } \\
\text { duration } \\
\text { (Days) }\end{array}$ & $\begin{array}{c}\text { Mean } \\
\text { apple } \\
\text { weight }(\mathbf{g})\end{array}$ & $\begin{array}{c}\text { Mean nut } \\
\text { weight(g) }\end{array}$ & $\begin{array}{c}\text { Nut } \\
\text { yield(Kg/ } \\
\text { plant) }\end{array}$ & $\begin{array}{c}\text { Shelling } \\
\text { \% }\end{array}$ & $\begin{array}{c}\text { Cumulative } \\
\text { yield } \\
\text { (3rd harvest) }\end{array}$ & $\begin{array}{c}\text { TMB } \\
\text { Infestation }\end{array}$ \\
\hline T1 & 119 & 33.68 & 6.65 & 3.18 & 30.16 & 6.42 & Low \\
\hline T2 & 117 & 33.94 & 6.82 & 3.53 & 30.16 & 7.42 & Low \\
\hline T3 & 119 & 33.60 & 6.71 & 3.28 & 31.00 & 6.70 & Low \\
\hline T4 & 119 & 34.56 & 6.76 & 3.41 & 31.02 & 7.07 & Low \\
\hline T5 & 117 & 33.25 & 6.60 & 3.09 & 30.04 & 6.20 & Low \\
\hline T6 & 119 & 33.21 & 6.57 & 3.02 & 29.07 & 6.01 & Low \\
\hline T7 & 121 & 35.82 & 7.05 & 4.18 & 31.05 & 8.65 & Low \\
\hline T8 & 124 & 36.42 & 6.93 & 4.05 & 31.08 & 8.56 & Low \\
\hline S.Em \pm & 0.92 & 0.44 & 0.05 & 0.07 & 0.17 & 0.19 & - \\
\hline CD at 5\% & 2.81 & 1.33 & 0.17 & 0.21 & 0.52 & 0.57 & - \\
\hline CV & 1.34 & 0.28 & 1.40 & 3.47 & 0.97 & 4.54 & - \\
\hline
\end{tabular}

In conclusion the different organic manures source of nutrients, bio fertilizers and naturally available materials combination treatments were investigated on growth and yield attributes of cashew. among the treatments, The $\mathrm{T}_{7}(25 \%$ as FYM+ Recycling of organic residue +in-situ green manuring/ green leaf manuring +BFC @ 200g/tree/year) and $\mathrm{T}_{8}$ (Recommended dose of fertilizer +10 $\mathrm{Kg}$ FYM) were found to be best treatments with reference to flowering duration in days, apple weight in grams, mean nut eight in grams, nut yield per plant in Kilograms and cumulative yield. However, $\mathrm{T}_{7}$ and $\mathrm{T}_{8}$ treatments were on par with each other, but the long-term goal of developing sustainable food systems is considered a high priority by several intergovernmental organisations (Axel Mie, et. al., 2017). Hence, organically cultivated produce have higher demand and higher health benefits by free from pesticide residues and heavy metals (Eva Johansson et. al., 2014) for this $\mathrm{T}_{7}$ was best treatment compared to other treatments.

\section{Acknowledgement}

The authors are highly grateful to the Director and Project Coordinator, ICAR-Directorate of Cashew Research, Puttur, Karnataka and the Director of Research, University Horticultural Sciences, Bagalkot for providing funds, facilities and necessary support for smoothly conducting the research.

\section{References}

Axel Mie, Helle Raun Andersen, Stefan Gunnarsson, Johannes Kahl, Emmanuelle Kesse-Guyot, Ewa Rembiałkowska, Gianluca Quaglio and Philippe Grandjean (2017) Human health implications of organic food and organic agriculture: a comprehensive review. Environmental Health 16:111

D. Kalaivanan and T.R. Rupa (2017), Organic cultivation of cashew, Cashew: Improvement, Production and 
Processing. Pages 295-322

Eva Johansson, Abrar Hussain, Ramune

Kuktaite, Staffan C. Andersson, and Marie E. Olsson. (2014) Contribution of Organically Grown Crops to Human Health. Int J Environ Res Public Health. 11(4): 3870-3893.

Maritus, C. H. T. and Vlelc,P. L. G. (2001) The management of organic matter in tropical soils: what are the properties? Nutr.Cycl.Agroecosyst. 61:1-16.

Panse, V. G. and Sukhatme, P. V. (1995). Statistical Method for Agricultural Workers. Fourth edition, ICAR Publication, New Delhi. pp 262-360.
Salas-Salvadó (2016). Nutritional composition of raw fresh cashew (Anacardium occidentale L.) kernels from different origin. Food Sci Nutr. 4(2): 329-338.

Seifritz, W. (1992). Alternative and renewable source of energy in optimizing yields. The role of fertilizers. Proceedings of $12^{\text {th }}$ IPI Congress. pp. 155-163.

Somani,L.L. and Totawat,K.L. (1996) soil conditioner and amendments.Agrotechpub.academy, Udaipur 1st Ed. pp. 28-160.

Ricard Rico, Mònica Bulló, and Jordi

\section{How to cite this article:}

Rajendra, B. N., M. Ramesh and Subramanyam, B. 2020. Impact of Different Organic Source of Manures, Bio-fertilizers, Rock phosphate, Green Manuring and Recycling of Organic Residue on Vegetative and Yield Traits Performance of Cashew Var. Ullal-1 under Plain Region of Karnataka. Int.J.Curr.Microbiol.App.Sci. 9(02): 1175-1180. doi: https://doi.org/10.20546/ijcmas.2020.902.138 